Araştırma makalesi

\title{
Determination of antioxidant and antimicrobial properties of Eremurus spectabilis Bieb.
}

\author{
Eremurus spectabilis Bieb.'in antioksidan ve antimikrobiyal özelliklerinin belirlenmesi \\ Burak BIRCAN, Sevda KIRBAĞ \\ Firat University, Faculty of Scince, Biology Department
}

\section{Abstract}

In this study, in vitro antioxidant and antimicrobial activities of the E. spectabilis Bieb., which is consumed as a vegetable among people, was investigated and Kluyveromyces lactis's antioxidant activies in anaerobic cultural environment is researched. This purpose; 2,2-diphenyl-1-picrylhydrazyl (DPPH) radical scavenging activity, flavonoid, resveratrol, sugar contents, lipid peroxidation (LPO) levels, fatty acid level, lipophilic vitamin values, protein and glutathione amounts were measured. In the $\mathrm{FeCl}$ group in which $\mathrm{FeCl}_{2}+\mathrm{H}_{2} \mathrm{O}_{2}$ is applied, when compared with LPO level control group (K), it was observed that it increase in high amount $(p<0.05)$. LPO level decreases in certain proportions in treatment groups. It is suggested that the lowering effect of the LPO of $E$. spectabilis extracts are arise from phytochemical like flavonoids that it includes. As a result of the antibacterial activity studies, it was observed that $E$. spectabilis have different proportional antimicrobial activities against E. coli, S. aureus, Epidermophyton spp. and C. albicans.

Keywords: Antimicrobial activity, DPPH; E. spectabilis, lipid peroxidation, vitamin, yeast culture

Özet

Bu çalışmada, halk arasında sebze olarak tüketilen E. spectabilis Bieb.'in in vitro antioksidan ve antimikrobiyal aktivitesi incelenmiş ve anaerobik kültür ortamında Kluyveromyces lactis üzerinde ki antioksidan aktivitesi araştırılmıştır. Bu amaçla; 2,2-difenil-1-pikrilhidrazil (DPPH) giderme aktivitesi, flavonoid, resveratrol, şeker içeriği, lipid peroksidasyon düzeyi, yağ asidi düzeyi, lipofilik vitamin değerleri, protein ve glutatyon miktarları ölçüldü. $\mathrm{FeCl}_{2}+\mathrm{H}_{2} \mathrm{O}_{2}$ uygulanan $\mathrm{FeCl}$ grubunda LPO seviyesinin kontrol grubuna (K) kıyasla yüksek miktarda arttığı görüldü $(p<0.05)$. Tedavi gruplarında da LPO düzeyinin belli oranlarda azaldığı belirlendi. Eremurus spectabilis'in LPO düşürücü etkisinin içerdiği flavonoidler gibi fitokimyasal kaynaklar olduğu ileri sürülmektedir. Antibakteriyel aktivite sonuçlarına göre E. spectabilis'in E. coli, S. aureus, Epidermophyton spp. ve C. albicans'a karşı farklı oranlarda antimikrobiyal aktiviteye sahip olduğu görülmektedir.

Anahtar kelimeler: Antimikrobiyal aktivite, DPPH, E. spectabilis, lipid peroksidasyonu, maya kültürü, vitamin

\section{INTRODUCTION}

Throughout history, a number of plants are discovered by people and they have transferred their experiences, while they using these plants on daily life, generations to generations.
Like many other plants in Anatolia, $E$ spectabilis which is a member of Liliaceae family, is consumed as a vegetable and used in the treatment of various diseases by individuals. The leaves of this plant (which is named as "Çiriş, Gullik" between individuals) is used against eczema, fungal infections and 
diabetes (Altundag and Ozturk 2011; Arıtuluk and Ezer 2012).

The essential oil and molecules and pharmacologic properties of this plant are examined and it is stated that its potentiality of the usage in industrial areas can be beneficial (Kırbag and Bagcı 2000). A great interest has occurred for the usage instead of synthetical oxidant and protectors, especially obtaining antioxidant and antimicrobial materials from natural materials. Recent studies show that plant materials include many phytochemical compounds that have strong antioxidant and antimicrobial materials (Yilmaz et al. 2010, Erden et al. 2013).

In this study, the phytochemical composition, antioxidant and antimicrobial capacities of $E$. spectabilis were examined in vitro. By this way, finding new antioxidant resources are aimed for treatments of the diseases.

\section{MATERIALS AND METHODS}

\section{Plant Material}

E. spectabilis were collected in the city of Elazığ in Turkey.

\section{Flavonoid and Resveratrol Content}

Plant samples were homogenized in 1:5 $(\mathrm{g} / \mathrm{mL})$ of $80 \%$ methanol. The homogenate was filtered through filter paper. Its flavonoid and resveratrol content were determined with High- performance liquid chromatography (HPLC) by putting $1 \mathrm{~mL}$ of filtrate in the autosampler vials ( $\mathrm{Zu}$ et al. 2006).

Flavonoid and resveratrol contents were quantified by diode array detector reversed phase-high performance liquid chromatography (DAD RP HPLC) separation. The separation was performed at $280 \mathrm{~nm}$ for catechin and naringin, $254 \mathrm{~nm}$ for rutin, myricetin, morin and quercetin, $306 \mathrm{~nm}$ for resveratrol and $265 \mathrm{~nm}$ for kaempferol. All chromatographic procedures at $25^{\circ} \mathrm{C}$ was performed.

\section{Phytosterol and Vitamin Analysis}

Vitamins and phytosterols were extracted from the lipid extracts by the method of (Sánchez-Moreno et al., 1999, LopezCervantes et al., 2006). Plant sample (1 g) was homogenized with $5 \mathrm{~mL}$ hexane and isopropyl alcohol $(3: 2, \mathrm{v} / \mathrm{v})$. The homogenate was filtered with filter paper. The filtrate was treated with $5 \mathrm{~mL}$ of $\mathrm{KOH}$ solution $(0.5 \mathrm{M}$ in methanol) and immediately vortexed. The tubes were placed in a water bath at $80^{\circ} \mathrm{C}$ for $15 \mathrm{~min}$.

After cooling in iced water, $1 \mathrm{~mL}$ of distilled water and $5 \mathrm{~mL}$ of hexane was added and the mixture was rapidly vortexed and then centrifuged for $5 \mathrm{~min}$ at $5.000 \mathrm{rpm}$. The detection from supernatant was operated using two channels of a diode-array spectrophotometer (326 nm for retinol and $202 \mathrm{~nm}$ for $\alpha$-tocopherol and phytosterols) (Lopez-Cervantes et al. 2006).

\section{Sugar Analysis of Plants}

Sugar compounds in the combined extracts were determined by using HPLC with a refractive index detector. Plant samples were homogenized in 1:1 $(\mathrm{g} / \mathrm{mL})$ of distilled water. Supernatant phase was separated from the pellet. After total filtrate volume was determined, sugar compounds were analyzed by HPLC device and Shimpack HRC$\mathrm{NH}_{2}(150 \times 4.6 \mathrm{~mm}, 5 \mu \mathrm{m})$ column was used (Grace 2004). 


\section{DPPH Free Radical Scavenging Activity}

E. spectabilis were extracted in $1: 5(\mathrm{~g} / \mathrm{mL})$ ratio with methanol. The free radical scavenging effect determinated by the method of Brand-Williams et al. (BrandWilliams et al., 1995).

$25 \mathrm{mg} / \mathrm{L}$ DPPH solution and methanol was prepared and $3.9 \mathrm{~mL}$ of this solution was mixed with 10, 25, 50 and $100 \mathrm{mg} / \mathrm{mL}$ concentrations of plant extracts. The reaction mixture was stored in darkness at room temperature for $30 \mathrm{~min}$. The absorbance of the mixture was measured spectrophotometrically at $517 \mathrm{~nm}$. The ability to scavenge DPPH radical was calculated by the following equation.

DPPH radical scavenging activity $(\%)=[($ Abs control-Abs sample)/(Abs control)] $\times 100$

Where Abs control is the absorbance of DPPH radical+methanol; Abs sample is the absorbance of DPPH radical+sample extract/standard. The IC50 (median inhibitory concentration) was calculated.

\section{Antioxidative Activity Testing of Plant Extracts}

Antioxidative activities of the plant extracts were determined. During the in vitro experiment;

Control Group (K): $5 \mathrm{~mL}$ trisma-base buffer, $0.4 \mathrm{~mL}$ fatty acid mixture

$\mathrm{FeCl}_{2}+\mathrm{H}_{2} \mathrm{O}_{2}$ Group ( $\mathrm{FeCl}$ ): $5 \mathrm{~mL}$ trisma-base buffer, $1 \mathrm{~mL} \mathrm{FeCl}, 1 \mathrm{~mL} \mathrm{H} \mathrm{O}_{2}, \quad 0.4 \mathrm{~mL}$ fatty acid mixture

Plant Group (ERA): $5 \mathrm{~mL}$ trisma-base buffer, 1 $\mathrm{mL} \mathrm{FeCl}, 1 \mathrm{~mL} \mathrm{H}_{2} \mathrm{O}_{2}, 0.4 \mathrm{~mL}$ fatty acid mixture, $1 \mathrm{~mL}$ Plant Extract
This groups were incubated at $37^{\circ} \mathrm{C}$ for $24 \mathrm{~h}$ Then, $100 \mu \mathrm{L}$ of a $4 \%(\mathrm{w} / \mathrm{v})$ Butylated hydroxytoluene (BHT) solution was added to prevent further oxidation. $1 \mathrm{~mL}$ was taken each mixture and $1 \mathrm{~mL}$ of $0.6 \%$ TBA was added to the reaction mixture and incubated at $90^{\circ} \mathrm{C}$ for $45 \mathrm{~min}$. Samples were allowed to cool to room temperature and the pink pigment produced was extracted with $3 \mathrm{~mL}$ of $n$-butanol.

Finally, the samples were then centrifuged at $6000 \mathrm{rpm}$ for $5 \mathrm{~min}$. and, the concentration of the upper butanol layer was measured by HPLC-fluorescence detector (Akkaya and Yilmaz, 2012).

\section{Determination of in Vitro LPO Level}

The products of peroxidation of fatty acids in vitro were determined by reading the fluorescence detector set at $\lambda$ (excitation) $=515 \mathrm{~nm}$ and $\lambda$ (emission) $=543$ $\mathrm{nm}$. Formation of the malonaldehyde in vitro expressed as thiobarbituric acid-reactive substances (TBARS) was calculated from a calibration curve using 1,1,3,3tetraethoxypropane as the standard. The MDA-TBA complex was analyzed using HPLC (Shimadzu, Kyoto Japan) (Akkaya and Yilmaz 2012, De Las Heras et al. 2003).

\section{Determination of the Remaining In Vitro Fatty Acids Level}

Remaining mixtures of fatty acids in the test tube were converted to methyl esters by using $2 \%$ sulfuric acid $(\mathrm{v} / \mathrm{v})$ in methanol. The fatty acid methyl ester forms were extracted with $\mathrm{n}$-hexane. Analysis was performed in gas chromatograph (Shimadzu GC- 17A). The results were expressed as $\mu \mathrm{mol} / \mathrm{mL}$ (Akkaya and Yilmaz 2012). 


\section{Antimicrobial Activity}

Extraction: The dried and powdered plant materials $10 \mathrm{~g}$ were extracted in $150 \mathrm{~mL}$ solvent by kept on a rotary shaker for $24 \mathrm{~h}$. Then, it was filtered through Whatman No. 1 filter paper. The sample were further concentrated to dryness under reduced pressure at $37^{\circ} \mathrm{C}$ using a rotary evapotor. It was dissolved in dimethyl sulfoxid and stored at $4^{\circ} \mathrm{C}$ for further studies.

\section{Well Agar Method}

Microorganisms have been provided from the culture collection of the Microbiology Laboratory of Science Faculty Firat Universty, Turkey. Staphylococcus aureus COWAN I, Escherichia coli ATCC 25922, Epidermophyton spp. and Candida albicans microorganisms have been used to investigate the antimicrobial activity of samples.

Antimicrobial tests were carried out by well agar method using $100 \mu \mathrm{L}$ of suspension containing 106 cells $/ \mathrm{mL}$ of bacteria, 104 cells $/ \mathrm{mL}$ yeast and cells $/ \mathrm{mL}$ dermatophyta fungi as per McFarland standard, inoculated into Mueller Hinton Agar (Difco), Malt Extract Agar (Difco) and Sabouroud Dextrose Agar (Oxoid), respectively. For agar well diffusion method, wells were prepared in the plates with the help cork-borer $(0.85 \mathrm{~cm})$. Steril petri dishes were placed at $4{ }^{\circ} \mathrm{C}$ for $2 \mathrm{~h}$. Then, the inoculated plates were incubated at $37 \pm 0.1^{\circ} \mathrm{C}$ at $24 \mathrm{~h}$ for bacterial strains and also at $25 \pm 0.1^{\circ} \mathrm{C}$ at $72 \mathrm{~h}$ for yeast and dermatophyta fungi. Antimicrobial activity was evaluated by measuring the zone of inhibition against the test organisms (Collins and Lyne 1987). Diameter of the clear zone around the disc is measured and compared against the inhibition produce by standard antimicrobial agent.

\section{Yeast Strain and Growth Conditions}

Malt Extract Broth (MEB) was prepared for growth of $K$. lactis COWAN 1.

Groups of this experiments;

Control (K): Only MEB with $K$. lactis

$\mathrm{FeCl}_{2}+\mathrm{H}_{2} \mathrm{O}_{2}$ Group (FeCl): $\mathrm{K}+\mathrm{H}_{2} \mathrm{O}_{2}+\mathrm{FeCl}_{2}$

Plant extract with $\mathrm{H}_{2} \mathrm{O}_{2}+\mathrm{FeCl}_{2}$ (ERA): $\mathrm{K}+$ Plant extract+(24th hour of incubation added $\mathrm{H}_{2} \mathrm{O}_{2}+\mathrm{FeCl}_{2}$ mixture)

All groups were then incubated at $27^{\circ} \mathrm{C}$ for 72 $h$. The growth rate was determined from the absorbance time course at $550 \mathrm{~nm}$.

\section{Preparation of Cell Extracts}

The end of $72 \mathrm{~h}$ incubation, were added $4 \%$ $\mathrm{BHT}$ into the all samples. This samples were centrifuged and separated pellet. This pellet was washed with phosphate buffer ( $\mathrm{pH}$ 7.4). After washing, $3 \mathrm{~mL}$ TEA buffer was added in the remaining pellet and sonication was performed for $40 \mathrm{sec}$. The samples centrifuged for $10 \mathrm{~min}$ at $4{ }^{\circ} \mathrm{C}, 9000 \mathrm{rpm}$. The supernatant was taken to the tubes in order to determine the amount of glutathione and protein. Hexane/isopropanol was added in the remaining pellet and fatty acid content in the medium was determined.

\section{Yeast Protein Concentration and Lipid Peroxidation Levels}

Protein concentration of yeast culture was determined according to the method of Lowry et al. (Lowry et al. 1951). using bovine serum albumin (Sigma-Aldrich) as the standard. Malondialdehyde (MDA) produced by the decomposition of lipid peroxides 
following the TBA reaction was monitored by spectrophotometer. For the MDA assay, $1 \mathrm{~mL}$ supernatant was mixed with $1 \mathrm{~mL}$ of $0.6 \%$ TBA $(\mathrm{w} / \mathrm{v})$ and $1 \mathrm{~mL}$ of $20 \%$ trichloroacetic acid $(w / v)$. The reaction mixture was incubated at $95^{\circ} \mathrm{C}$ for $2 \mathrm{~h}$. The analysis was performed according to the measurement of in vitro antioxidant capacity. The results were expressed as $\mu \mathrm{mol} / \mathrm{g}$ yeast.

Determination of Glutathione Levels and SDS-PAGE Analysis

Yeast glutathione levels were determined according to the method of Ellman using a UV-VIS spectrophotometer at the wavelength $412 \mathrm{~nm}$ (Ellman 1959). Standard curve was prepared with known concentrations of glutathione. Results were expressed in $\mathrm{nmol} / \mathrm{mg}$. Total protein extractions method was performed according to Wang et al. (Wang et al. 1996). Protein samples were analyzed as described by Laemmli (Laemmli 1970). $50 \mu \mathrm{g}$ of yeast extract from the sample was loaded on each lane (10 $\mu \mathrm{L}$ solution), and a molecular weight marker solution (Thermo Scientific Unstained Protein Molecular Weight Marker) was loaded at either end of the gel. Electrophoresis was performed at $20 \mathrm{~mA}$ per gel. The gel was stained in Coomassie Brilliant Blue (Sigma Aldrich Chemie, Germany) solution for $30 \mathrm{~min}$ at $67^{\circ} \mathrm{C}$ and destained in destaining solution for $3-4 \mathrm{~h}$ at $67^{\circ} \mathrm{C}$ to visualise the proteins.

\section{Statistical Analysis}

Statistical analysis was performed using SPSS software (version 15.0). The experimental results were reported as mean \pm SEM (standard error of means). Analysis of variance (ANOVA) and least significant difference (LSD) test were used to compare the experimental groups with the controls. The results were considered statistically significant for $\mathrm{p}<0.05$.

\section{RESULTS AND DISCUSSION}

\section{Plant Contents}

\section{Flavonoid and resveratrol contents of the $E$.} spectabilis

According to the results of flavonoid and resveratrol analysis rutin, morin, quarcetin and resveratrol were found in E. spectabilis. On the other hand, myricetin, kaempferol, catechin, naringin and naringenin were not found in E. spectabilis used in the study (Table 1). As far as our literature investigation could investigate, there were no results on flavonoid and resveratrol contents of $E$. spectabilis. Therefore, this study may have provide new findings on this plant.

Flavones and flavonols are subgroups of flavonoids. Flavonols are known to act as antioxidants, both as radical scavengers and as metal chelators (Bors and Saran 1987). The flavonols, quercetin and myricetin are the two most active compounds in retarding hydroperoxide formation. In addition, the aglycones of these flavonols were reported to be more active than their glycosides (Hopia and Heinonen 1999).

It is supposed that the antioxidant effect of a flavonoid-rich nutrition is stronger than even vitamins A and C (Sokół-Łętowska et al. 2007). The herbal flavonoid and other polyphenolic compounds have many biological effects including antiinflammatory, antimicrobial, anti-tumour and platelet aggregation inhibition (Prior 2003, Formica and Regelson 1995). 


\section{Vitamin and phytosterol contents of the $E$.} spectabilis

In E. spectabilis, vitamin $\mathrm{K}$, vitamin $\mathrm{D}, \alpha$ tocopherol ergosterol and $\beta$-sitosterol were determined. Vitamin $D$ and $\beta$-sitosterol content were higher than the other vitamins (Table 1).

Plant sterols are naturally occurring molecules that humanity has evolved with, which partially counter the absorption of dietary cholesterol and have other important biological functions described above. Consumption from natural sources should be encouraged for all persons, and consumption of plant sterols in enriched sources should be encouraged following consultation with a clinician. The clinician should be assured that the individual is a responder to plant sterols, and achieves a reduction in LDL cholesterol. Along these lines, it would be fruitful to monitor individuals for markers of cholesterol absorption before recommending consumption of enriched plant sterols (Berger et al. 2004).

\section{Sugar contents of the E. spectabilis}

The existence of arabinose, fructose, glucose and saccharose was determined from $E$. spectabilis.

According to the results of our study, highest glucose and fructose amounts were seen in this plant (Table 1). All these data have shown that different Eremurus species contains sugar in varying ratios.

In some of the studies that made with Eremurus species, the galactomannan and polysaccharides contents increased and high content of galactomannan were determined. Other hand $E$. persicus was used as an antidiabetic agent in Iranian traditional medicine (Asgarpanah et al. 2013).

Table 1. Flavonoids, Resveratrol, Vitamin, Phytosterol and Sugar content in E. spectabilis $(\mu \mathrm{g} / \mathrm{g}$ )

\begin{tabular}{llllll}
\hline $\begin{array}{l}\text { Flavonoids \& } \\
\text { Resveratrol }\end{array}$ & & $\begin{array}{l}\text { Vitamin \& } \\
\text { Phytosterol }\end{array}$ & & Sugars \\
\hline Rutin & $216 \pm 1.01$ & Vitamin K & $0.113 \pm 0.03$ & Arabinose & $71.91 \pm 0.80$ \\
Myricetin & - & Retinol & - & Fructose & $668.66 \pm 25.32$ \\
Morin & $0.17 \pm 0.01$ & Vitamin D & $3.420 \pm 0.07$ & Glucose & $2470.08 \pm 16.99$ \\
Quarcetin & $0.17 \pm 0.2$ & $\alpha$-Tocopherol & $0.306 \pm 0.04$ & Sucrose & $42.57 \pm 18.79$ \\
Kaempferol & - & Ergosterol & $0.680 \pm 0.11$ & Maltose & $189.28 \pm 38.01$ \\
Catechin & - & Stigmasterol & - & & \\
Naringin & - & $\beta$-Sitosterol & $13.970 \pm 0.55$ & & \\
Naringenin & - & & & & \\
Resveratrol & $0.86 \pm 0.02$ & & & & \\
\hline
\end{tabular}

Each value is the mean \pm standard deviation of five determinations.

DPPH Free Radical Scavenging Activity

DPPH free radical scavenging activity of the plant samples was shown in the Table 2.

DPPH free radical scavenging activity were determined from $10 \mu \mathrm{L}$ to be effective. This effect might occur because of the influence of flavonoids, phytosterols and vitamins inside the plant. The results comply with the findings of the existing literature (Taskin et al. 2012). These results indicate that $E$. spectabilis have beneficial effects on DPPH radical scavenging ability and may thus protect against oxidative damage. 
Table 2. Inhibition \% of DPPH radical at steady state among different concentrations of plant extracts, and median inhibitory concentration (IC50) value for E. spectabilis.

\begin{tabular}{|c|c|c|c|c|c|}
\hline Extract & $2 \mathrm{mg} / \mathrm{mL}$ & $5 \mathrm{mg} / \mathrm{mL}$ & $10 \mathrm{mg} / \mathrm{mL}$ & $20 \mathrm{mg} / \mathrm{mL}$ & IC50 \\
\hline E. spectabilis & $5 \pm 0.36$ & $10.57 \pm 0.98$ & $27.93 \pm 1.49$ & $60.57 \pm 4.07$ & $32.285 \pm 1.72$ \\
\hline
\end{tabular}

Values were expressed as mean \pm standard error $(n=3)$.

\section{Determination of LPO Level}

In vitro lipid peroxidation level showed a significant increase in the $\mathrm{FeCl}$ group as compared to the $\mathrm{K}$ group $(\mathrm{p}<0.05)$. Meanwhile, the peroxidation levels decreased in the ERA group as compared to the $\mathrm{FeCl}$ group $(\mathrm{p}<0.05)$ (Figure 1.).

In this study, the reduction of the elevated LPO levels which was determined only in the $\mathrm{FeCl}$ group is believed to be related to its flavonoid ingredient. The flavonoid ingredients of $E$. spectabilis consist of quercetin, resveratrol and rutin (Table 1 ). Flavonoids have a number of biological effects in vivo and in vitro (Shimoi et al. 1994, Di Carlo et al. 1999) and many studies have reported the antioxidant activity of plant extract and their relationship with the phenolic compound content (Akkaya and Yilmaz 2012).

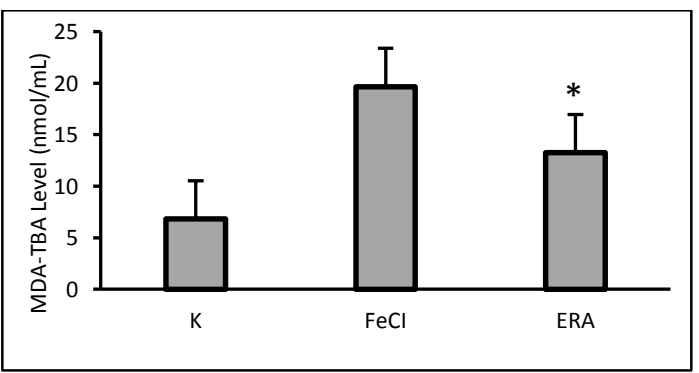

Figure 1. Determination of LPO level in vitro environment from E. spectabilis (ERA has decreased according to $\mathrm{FeCl} . *$ : $p<0.05)$

\section{Determination of The Remaining Fatty Acids Level}

Analysis results of fatty acid were shown in Figure 2. In comparison with the $\mathrm{K}$ group, amounts of oleic acid and linoleic acid showed decrease in $\mathrm{FeCl}$ group, and this decrease was found statistically significant. ERA group were compared with the $\mathrm{K}$ and $\mathrm{FeCl}$ groups, an increase was seen in the amount of fatty acids. This increase was significant of $\mathrm{FeCl}$ and ERA groups $(*: p<0.05)$.

For the fatty acids level, we suggest that the flavonoids of these extracts may protect unsaturated fatty acids from attacks of free radicals. Pekkarinen et al. (1999) reported that the antioxidant activity of the flavonoids quercetin, myricetin, kaemferol, catechin, and rutin on methyl linoleate oxidation (Pekkarinen et al. 1999). They reported that the antioxidant activity of flavonoids in the methyl linoleate system is due to radical scavenging activity and flavonoids may effect the decomposition of hydroperoxides.

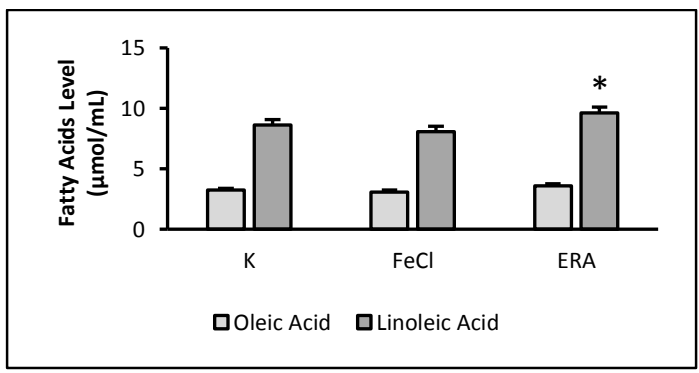

Figure 2. The effect of E. spectabilis on K.lactis's Fatty Acids Level $(\mu \mathrm{mol} / \mathrm{mL}$ ) (ERA has increased according to $\left.\mathrm{FeCl}^{*}: \mathrm{p}<0.05\right)$

The Effects of E. spectabilis Extracts on Lipid Peroxidation of $K$.lactis

Analysis results of yeast culture lipid peroxidation are shown in Figure 3 . Compared to the $\mathrm{K}$ group, levels of lipid peroxidation showed a significant decrease in 
$\mathrm{FeCl}$ group. Between the $\mathrm{K}$ and ERA groups, no statistical significance was found in regard to their lipid peroxidation level $(*: p<0.05)$.

The reason of these different findings reoccupy that the microorganisms show different resistance towards free radical damage of microorganisms. Recent studies exhibit that $\mathrm{H}_{2} \mathrm{O}_{2}$ is not freely diffuse in some cell biomembranes. It was stated that there exist a barrier system against the diffusion of $\mathrm{H}_{2} \mathrm{O}_{2}$ in the cells of; firstly E. coli, S. cerevisiae and Jurkat-T which is a kind of mammalian. It is said that this effect depends on the concentration of $\mathrm{H}_{2} \mathrm{O}_{2}$, the yeast cell shows adaptation against low level of $\mathrm{H}_{2} \mathrm{O}_{2}$, and show resistance to high level of $\mathrm{H}_{2} \mathrm{O}_{2}$ (Folmer et al. 2008). Previous report observed that when the plasma membrane of $S$. cerevisiae is exposed to $\mathrm{H}_{2} \mathrm{O}_{2}$, it changes its permeability and physiological property rapidly in few minutes and it is propound that this change cause from the changes in lipid composition (Folmer et al. 2008). They were emphasizes in a study that Kluveromyces marxianus is quite resistant to oxidative stress. In a cultural medium that is complicated by increasing Table 3. The effect of $E$. spectabilis extracts on $K$. lactis's fatty acids profile $(\mathrm{mg} / \mathrm{g}$ )

\begin{tabular}{llll}
\hline Fatty Acids/Groups & $\mathrm{K}$ & $\mathrm{FeCl}$ & $\mathrm{ERA}$ \\
\hline $16: 0$ & $0.363 \pm 0.003$ & $0.919 \pm 0.005$ & $0.161 \pm 0.02 *$ \\
$16: 1$ & $0.118 \pm 0.001$ & $0.171 \pm 0.002$ & $0.080 \pm 0.03^{*}$ \\
$18: 0$ & $0.507 \pm 0.007$ & $0.638 \pm 0.007$ & $0.072 \pm 0.02 *$ \\
$18: 1$ & $0.081 \pm 0.002$ & $0.337 \pm 0.007$ & $0.048 \pm 0.45^{*}$ \\
$18: 2$ & $0.126 \pm 0.007$ & $0.340 \pm 0.04$ & $0.113 \pm 0.03^{*}$ \\
$18: 3$ & $0.049 \pm 0.004$ & $0.146 \pm 0.008$ & $0.236 \pm 0.07^{*}$ \\
Others & $0.082 \pm 0.002$ & $0.761 \pm 0.004$ & $0.089 \pm 0.03^{*}$ \\
\hline
\end{tabular}

Each value is the mean \pm standard deviation of five determinations. $\left({ }^{*}: p<0.05\right)$

According to the results of fatty acid levels ERA group were compared with the $\mathrm{FeCl}$ group, an increase was seen in the amount of fatty acids profile. According to these results suggested that the flavonoids of these chemicals (50 $\mathrm{mM} \mathrm{H}_{2} \mathrm{O}_{2}$ ), which is a stress factor, and environment conditions, the viability of these species varies between $68 \%$ and $95.2 \%$. these results proves that Kluveromyces shows high resistance against high-dose chemicals and adverse environmental conditions (Pinheiro et al. 2002).

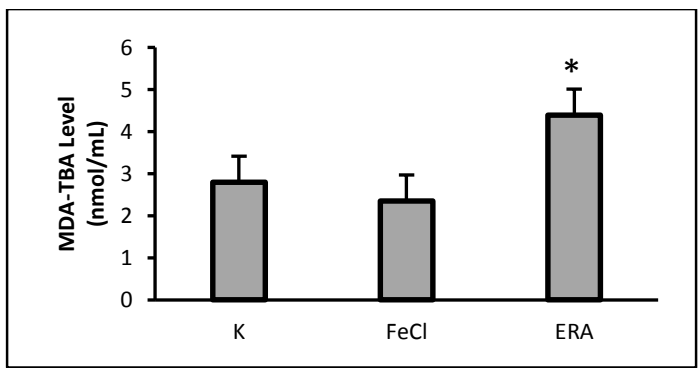

Figure 3. The effect of E. spectabilis on K.lactis's MDATBA level $(\mathrm{nmol} / \mathrm{mL}$ ) (ERA has increased according to FeCl.*:p<0.05)

\section{The Effect of E. spectabilis Extracts on $K$. latis's Faty Acid Profile}

Palmitic acid (16:0), Palmitoleic acid (16:1), Stearic acid (18:0), Oleic acid (18:1), Linoleic acid (18:2), Linolenic acid (18:3) and other fatty acids amount were determined in this study (Table 3). 
the "transcribs" of the fatty acids lead differences in the amount of fatty acid by inhibited or stimulated of these fatty acids, since the carbon source of the yeast that used from curd power is different (Mcdonough and Roth 2005).

The Effect of E. spectabilis's Extracts on $K$. lactis's Glutathione Amount

When glutathione amounts compared with $\mathrm{K}$ group, it determined that the $\mathrm{FeCl}$ group decreased significantly, but when compared with $\mathrm{FeCl}$ group ERA group increases distinctively $(p<0.01)$ (Figure 4$)$. When the glutathione amounts of $\mathrm{K}$. lactis is compared with $\mathrm{K}$ group, it is seen that there is a decrement in $\mathrm{FeCl}$ group.

The reason of this situation can be correlated with the flavonoid, phytosterol and vitamin values of plant samples and different biochemical properties of microorganisms and also; it is thought that flavonoids reduce oxidative damage in the minimum amount by inhibiting the radicals, which are added to the culture medium, in early stage. In this situation, the lack the amount of glutathione can be associated with the amount of flavonoid.

In the other study, as a result of the oxidative stress which is caused by hydrogen peroxide and paraquat addition, the antioxidant enzyme levels of $K$. marxianus and viability level of the organism in different air pressures are tested. As a result, the amounts of superoxide dismutase (SOD), catalase (CAT) and the glutathione reductase increase after adding chemicals. In the study which is about investigation of the enzyme level changes after increasing the pressure, it is found that firstly enzyme levels increase with increasing pressure however this increment decreased in time (Pinheiro et al. 2002).

All these findings show that the level of protein synthesis changes across different environment conditions. Additionally, the oxidation is tolerated by the microorganism with respect to time meaning that while the rate of protein synthesis in the oxidation of acute phase increases, the expression decreases with time.

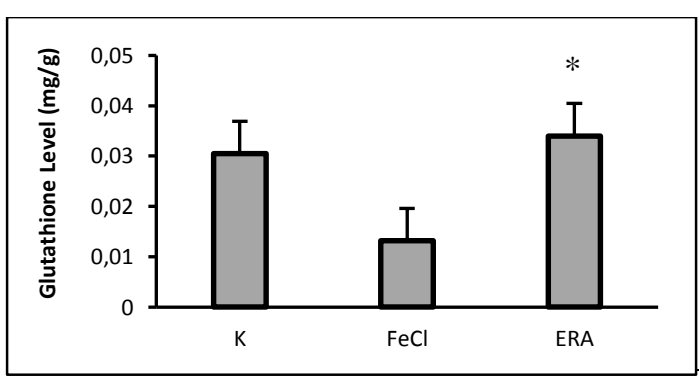

Figure 4. The effect of $E$. spectabilis extracts on $K$. lactis's glutathione amount (mg/g) (ERA has increased according to $\left.\mathrm{FeCl} .^{*}: \mathrm{p}<0.01\right)$

The Effect of $E$. spectabilis Extracts on $K$. lactis's Total Protein Amount

When examining the effects of $E$. spectabilis extracts on the total protein amount of $K$. Lactis, it is found that all groups are high according to $\mathrm{K}$ group but ERA group decrease with respect to $\mathrm{FeCl}$ group $(\mathrm{p}<0.05)$ (Figure 5). This situation is reoccupied that plant extracts protect the cell proteins. We think that this difference is due to the incubation time and biochemical and physiological variability of species.

When examining the effects of $E$. spectabilis extracts on the total protein amount of $K$. Lactis, it is found that all groups are high according to $\mathrm{K}$ group but ERA group decrease with respect to $\mathrm{FeCl}$ group $(\mathrm{p}<0.05)$ (Figure 5 ). This situation is reoccupied that plant extracts protect the cell proteins. We think that this difference is due to the incubation 
time and biochemical and physiological variability of species.

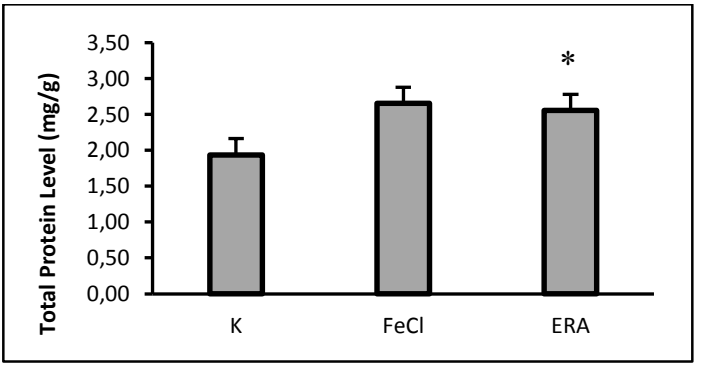

Figure 5. The effect of $E$. spectabilis extracts on $K$. lactis's total protein amount (mg/g) (ERA has decreased according to $\mathrm{FeCl} . *$ : $p<0.05$ )

\section{SDS-Page Analysis of $\boldsymbol{K}$. lactis}

SOD and CAT enzyme activities were investigated in this study. SOD line was not given any result in experiment groups on the SDS-Page. When CAT amount is examined, the specificity of protein bands and expression amount of this enzyme increase in ERA group. In $\mathrm{K}$ and $\mathrm{FeCl}$ group, the weakness of the protein bands means that the expression level is low in these groups (Figure 6).

\section{CAT $\mathrm{K} \quad \mathrm{FeCl}$ ERA}

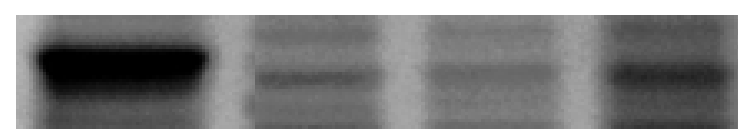

Figure 6. SDS-Page analysis of K.lactis

\section{Antimicrobial Activity of E. spectabilis}

The antimicrobial activities from $E$. spectabilis were determined. Methanol was used as a control and zone of inhibition was seen in $8 \mathrm{~mm}$ with only S. aureus. When used extract of $E$. spectabilis, zone of inhibition was seen on S. aureus: $12 \mathrm{~mm}$, E.coli: $14 \mathrm{~mm}$, C.albicans: $9 \mathrm{~mm}$ and E. sp.: $8 \mathrm{~mm}$. It was observed that $E$. spectabilis is more effective on microorganism groups compared with control group, this impact is more significant in bacteria groups compared with yeast and dermofit funguses.

\section{CONCLUSIONS}

The result of our findings will be guidance for the future studies which can be made about the usage natural antioxidants and antimicrobials on E. spectabilis. Because, since the usage of synthetic antioxidants have some side effects and the resistance against the synthetic antimicrobials and on behalf of natural antimicrobials for the resistance of synthetic antimicrobials, the researches in the area of the natural antioxidants and antimicrobials become a remarkable study topic in recent years with evolving technical requirements. The obtaining, detecting and exhibiting the natural antioxidants, which have more efficient and less side effects, are rank as an important expectations for life quality.

\section{ACKNOWLEDGEMENT}

This work was supported by Scientific Research Projects Coordination Unit of Firat University (Project: 2119). Thank you for contribution of Ökkeş Yılmaz (HPLC and gas chromatograph studies) and Abdullah Aslan (SDS Page Analysis).

\section{REFERENCES}

Akkaya H, Yilmaz O (2012) Antioxidant capacity and radical scavenging activity of Silybum marianum and Ceratonia siliqua, Ekoloji 21: 9-16

Altundag E, Ozturk M (2011) Ethnomedicinal studies on the plant resources of east Anatolia, Turkey, Procedia-Social and Behavioral Sciences 19: 756777

Arıtuluk Z C, Ezer N (2012) Halk Arasında Diyabete Karşı Kullanılan Bitkiler (Türkiye)-II, Hacettepe Üniversitesi Eczacılık Fakültesi Dergisi 2: 179-208

Asgarpanah J, Amin G, Parviz M (2013) In vitro antiglycation activity of Eremurus persicus (Jaub. Et 
Sp.) Boiss, African Journal of Biotechnology 10: 11287-11289

Berger A, Jones P, Abumweis S S (2004) Plant sterols: factors affecting their efficacy and safety as functional food ingredients, Lipids Health Dis 3: 119

Bors W, Saran M (1987) Radical scavenging by flavonoid antioxidants, Free Radical Research 2: 289-294

Brand-Williams W, Cuvelier M, Berset C (1995) Use of a free radical method to evaluate antioxidant activity, LWT-Food Science and Technology 28: 25-30

Collins C, Lyne P (1987) Microbiological Methods Butter Morths\&Co (Publishers) Ltd. London. 450pp

De Las Heras A, Schoch A, Gibis M, Fischer A (2003) Comparison of methods for determining malondialdehyde in dry sausage by HPLC and the classic TBA test, European food research and technology 217: 180-184

Di Carlo G, Mascolo N, Izzo A A, Capasso F (1999) Flavonoids: old and new aspects of a class of natural therapeutic drugs, Life sciences 65: 337-353

Ellman G L (1959) Tissue sulfhydryl groups, Archives of biochemistry and biophysics 82: 70-77

Erden Y, Bircan B, Yılmaz Ö, Erecevit P (2013) Antioxidative Activity and Phytochemical Composition of Dried Apricot, Turkish Journal of Science \& Technology 8: 107-113

Folmer V, Pedroso N, Matias A C, Lopes S C, Antunes F, Cyrne L, Marinho H S (2008) H2O2 induces rapid biophysical and permeability changes in the plasma membrane of Saccharomyces cerevisiae, Biochimica et Biophysica Acta (BBA)Biomembranes 1778: 1141-1147

Formica J, Regelson W (1995) Review of the biology of quercetin and related bioflavonoids, Food and chemical toxicology 33: 1061-1080

Grace C 2004. Chromatography A. A Grace Company Catolog 600. Alltech Associates Inc, U.S

Hopia A, Heinonen M (1999) Antioxidant activity of flavonol aglycones and their glycosides in methyl linoleate, Journal of the American Oil Chemists' Society 76: 139-144

Kırbag S, Bagcı E (2000) An Investigation on The Antimicrobial Activity of The Picea abies (L.) KARST and Picea orientalis (L.) LINK Essential Oils, Journal of Qafqaz University 3: 183-190

Laemmli U K (1970) Cleavage of structural proteins during the assembly of the head of bacteriophage T4, Nature 227: 680-685

Lopez-Cervantes J, Sanchez-Machado D, Rios-Vazquez N (2006) High-performance liquid chromatography method for the simultaneous quantification of retinol, $\alpha$-tocopherol, and cholesterol in shrimp waste hydrolysate, Journal of Chromatography A 1105: 135-139

Lowry O H, Rosebrough N J, Farr A L, Randall R J (1951) Protein measurement with the Folin phenol reagent, J biol Chem 193: 265-275

Mcdonough V M, Roth T M (2005) Growth temperature affects accumulation of exogenous fatty acids and fatty acid composition in Schizosaccharomyces pombe, Antonie van Leeuwenhoek 86: 349-354

Pekkarinen S S, Heinonen I M, Hopia A I (1999) Flavonoids quercetin, myricetin, kaemferol and (+)catechin as antioxidants in methyl linoleate, Journal of the Science of Food and Agriculture 79: 499-506

Pinheiro R, Belo I, Mota M (2002) Oxidative stress response of Kluyveromyces marxianus to hydrogen peroxide, paraquat and pressure, Applied microbiology and biotechnology 58: 842-847

Prior R L (2003) Fruits and vegetables in the prevention of cellular oxidative damage, The American journal of clinical nutrition 78: 570S-578S

Sánchez-Moreno C, Larrauri J A, Saura-Calixto F (1999) Free radical scavenging capacity and inhibition of lipid oxidation of wines, grape juices and related polyphenolic constituents, Food Research International 32: 407-412

Shimoi K, Masuda S, Furugori M, Esaki S, Kinae N (1994) Radioprotective effect of antioxidative flavonoids in $\gamma$-ray irradiated mice, Carcinogenesis 15: 26692672

Sokół-Łętowska A, Oszmiański J, Wojdyło A (2007) Antioxidant activity of the phenolic compounds of hawthorn, pine and skullcap, Food Chemistry 103: 853-859

Taskin T, Bitis L, Birteksöz S (2012) Antioxidant and antimicrobial activities of different extracts from Eremurus spectabilis leaves, Spatula DD-Peer Reviewed Journal on Complementary Medicine and Drug Discovery 2: 213-217

Wang K, Posner A, Hajimohammadreza I (1996) Total protein extraction from cultured cells for use in electrophoresis and western blotting, BioTechniques 20: 662-668

Yilmaz O, Ozsahin A D, Bircan B, Erden Y, Karaboga Z (2010) Radical Scavenging Activity of the Pistacia terebinthus in Fenton Reagent Environment and Its Protective Effects on the Unsaturated Fatty Acids, Asian Journal of Chemistry 22: 7949

Zu Y, Li C, Fu Y, Zhao C (2006) Simultaneous determination of catechin, rutin, quercetin kaempferol and isorhamnetin in the extract of sea buckthorn (Hippophae rhamnoides L.) leaves by RPHPLC with DAD, Journal of Pharmaceutical and Biomedical Analysis 41: 714-719. 